\title{
KOMPETENSI PEDAGOGIK DAN KEDISIPLINAN GURU-GURU SD YANG BERSERTIFIKASI PENDIDIK DI KECAMATAN TEPUS GUNUNG KIDUL
}

\author{
Wartomo \\ UPBJJ-UT YOGYAKARTA \\ Email:wartomo@ecampus.ut.ac.id
}

\begin{abstract}
Abstrak
Dalam proses pendidikan selalu diarahkan ke peningkatan kualitasnya. Usaha pemerintah untuk meningkatkannya salah satunya melalui pemberian sertifikasi pendidik kepada para guru. Dalam hal ini perlu diadakan penelitian yang bertujuan mengetahui sejauhmana kemampuan kompetensi pedagogik dan kedisiplinan kerja guru-guru SD yang bersertifikasi pendidik di Kecamatan Tepus, Gunung Kidul. Untuk mencapai tujuan penelitian tersebut maka diadakan penelitian dengan pendekatan kuantitatif korelasional. Penentuan subyek menggunakan teknik quota area random sampling. Jumlah subyek 25\% dari jumlah anggota populasi dan masing-masing desa pada Kecamatan Tepus diambil sesuai jumlahnya. Teknik pengumpulan data menggunakan metode observasi, dokumentasi sebagai metode pokok, dan interview sebagai metode pelengkap. Kesimpulan penelitian ini adalah kemampuan kompetensi pedagogik guru-guru SD yan sudah bersertifikasi pendidik dalam kondisi bagus (83\%), dan kedisiplinan kerjanya dalam kondisi bagus pula (75\%). Disarankan selalu dilaksanakan monitoring dan pembinaan terhadap guru-guru SD supaya tetap menampilkan kompetensi pedagogik dan kedisiplinan kerja semakin bagus demi peningkatan kualitas pendidikan.
\end{abstract}

Kata Kunci: Kompetensi pedagogik, kedisiplinan kerja, dan sertifikasi pendidik.

\section{PENDAHULUAN}

Pada proses pendidikan untuk mencapai tujuan negara dan meningkatkan kualitas manusia Indonesia, guru mempunyai peranan yang sangat penting. Emil Salim (dalam : L. Wilardjo, Harian Kompas, 26 Februari $2014: 7$ ) menyatakan untuk memperbaiki mutu pendidikan, kuncinya adalah guru. Selain itu tentu diperlukan sarana dan prasarana pendidikan, serta kurikulum. Namun di atas semua itu yang penting lagi adalah guru. Palupi Panca Astuti (Harian Kompas, 2 Maret 2006 : 14) menyatakan agen utama proses pendidikan adalah guru, karena guru yang paling bertanggungjawab dalam membelajarkan siswanya. Sebaik apapun kurikulumnya, sebaik apapun gedung sekolah dan perpustakaan, jika tidak dibarengi guru yang berkualitas, maka semuanya sia-sia. Sebaliknya, kurikulum yang kurang baik, gedung sekolah yang serdehana, perpustakaan sekolah seadanya, jika ditopang guru yang berkualitas akan dapat mencapai tujuan pendidikan dengan sangat baik. Oleh karena itu peningkatan mutu guru, sepatutnya menjadi perhatian utama dalam peningkatan mutu pendidikan.

Pada kenyataannya, kualitas guru di Indonesia terutama guru $\mathrm{SD}$, sangat 
memprihatinkan. Hasil penelitian Badan Pendidi Penelitian dan Pengembangan Kementerian Pendidikan dan Kebudayaan (Harian Kompas, 26 September 2012:12) mengatakan 62,73 persen guru SD tidak layak menjadi guru. Hasil penelitian Giyono (2010) menyimpulkan kemampuan mengajar guru-guru SD di Kecamatan Kretek, Bantul rendah. Penelitian Warniasih (2011), para guru SD di Kabupaten Bantul dalam memanfaatkan alat peraga pembagian pemerintah rendah. Penelitian Sugiman dan Giyono (2001) menyimpulkan para guru SD di Kabupaten Kulon Progo, kurang mampu menggunakan alat peraga dalam pembelajaran matematika.. Data di atas kompetensi pedagogik para guru SD masih rendah.

Sedangkan penelitian dalam bidang kedisiplinan kerja guru SD, penelitian Giyana (2006) menyimpulkan para guru SD di Kecamatan Kretek, Bantul, kurang disiplin dalam melaksanakan pembelajaran. Masih banyak guru terlambat masuk kelas, terutama sesudah jam istirahat.. Penelitian Ukhyumiani, dkk (2003), menyimpulkan kedisiplinan guru-guru SD di Kecamatan Kasihan Bantul, rendah. Berbagai hasil penelitian di atas, menunjukkan bahwa kedisiplinan guru SD juga masih rendah. Salah satu faktor yang sering disebut sebagai salah satu penyebab rendahnya kinerja dan kedisiplinan guru adalah rendahnya kesejahteraan guru.

Pemerintah telah berusaha meningkatkan kesejahteraan guru melalui sertifikasi guru dalam jabatan, yakni proses pemberian sertifikat pendidik untuk guru dalam jabatan. Program sertifikasi guru ini diikuti oleh guru yang telah memiliki kualifikasi akademik Sarjana (S-1) atau Diploma 4 (D-4). Konsekuensinya guru Pegawai Negeri Sipil (PNS) dan non Pegawai Negeri Sipil yang diangkat Badan Hukum Penyelenggaraan Pendidikan yang telah memiliki sertifikasi pendidik dan telah melaksanakan beban kerja sekurangkurangnnya 24 jam (24 jam tatap muka dalam satu minggu) berhak menerima tunjungan profesi pendidik sebesar satu kali gaji pokok yang dibayarkan melalui APBD atau APBN (Peraturan Menteri Pendidikan Nasional RI Nomor 18 tahun 2007). Hal ini merupakan salah satu upaya untuk meningkatkan pengabdian dan kompetensi guru guna meningkatkan mutu pendidikan.

Upaya pemerintah meningkatkan kesejahteraan guru melalui sertifikat pendidik, kadang-kadang disambut negatif oleh para guru. Muncul perbedaan persepsi, antara pemerintah dan guru dalam hal pelaksanaan sertifikasi. Disatu sisi 
pemenrintah sudah berniat baik melaksanakan sertifikasi sebagai proses untuk meningkatkan mutu guru. Namun disisi lain yang terjadi di kalangan guru saat ini hanya memandang sertifikasi sebagai proses peningkatan gaji guru, (Sumardi, Harian Kedaulatan Rakyat, Selasa 3 Februari 2009). Salah satu dampak dari situasi ini adalah guru yang seadanya mengajar, tidak disiplin, tidak menyiapkan diri untuk pekerjaan di kelas secara baik. Guru seperti ini lebih mengejar persyaratan mengajukan uji sertifikasi dan akibatnya kompetensi guru tidak meningkat. Masalah ini menimbulkan kecemburuan sosial dari guru-guru yang belum memenuhi syarat mengajukan sertifikasi. Guru-guru ini kadang-kadang harus menggantikan guru kelas guru yang mempersiapkan uji sertifikasi (Susilowati, Harian Kedaulatan Rakyat, Selasa 2 Februari 2009).

Menurut Peraturan Pemerintah Republik Indonesia, Nomor 74 tahun 2008 tentang Guru, pasal 2, dinyatakan bahwa guru wajib memiliki kualifikasi akademik, kompetensi, sertifikasi pendidik, sehat jasmani dan rohani serta memiliki kemampuan untuk mewujudkan tujuan pendidikan nasional. Kompetensi guru sebagaimana dimaksud tersebut di atas, meliputi kompetensi pedagogik, kompetensi

kepribadian, kompetensi sosial dan kompetensi profesional.

Kompetensi pedagogik merupakan kemampuan guru dalam pengelolaan pembelajaran peserta didik yang sekurangkurangnya meliputi: (a) pemahaman wawasan atau landasan kependidikan, (b) pemahaman terhadap peserta didik, (c) pengembangan kurikulum atau silabus, (d) perancangan pembelajaran, (e) pelaksanaan pembelajaran yang mendidik dan dialogis, (f) pemanfaatan teknologi pembelajaran, (g) evaluasi hasil belajar, dan (h) pengembangan peserta didik untuk mengaktualisasikan berbagai potensi yang dimilikinya (Peraturan Pemerintah RI, No. 74 tahun 2008). Kemampuan guru mewujudkan keempat jenis kompetensi tersebut juga dibuktikan dengan kehadiran bekerja atau bertugas dengan tepat waktu, mengajar tepat waktu, dan pulang kerja juga tepat waktu. Kedisiplinan guru diharapkan akan meningkat sesudah memliki sertifikat pendidik, karena dalam proses pencapaian sertifikat pendidik sangat memerlukan kedisiplinan kerja.

Dengan demikian, maka penelitian ini, dilakukan untuk mengetahui sejauhmana kompetensi pedagogik dan kedisiplinan kerja guru-guru SD, sesudah mendapat sertifikasi pendidik. 


\section{METODE PENELITIAN}

Penelitian ini merupakan penelitian dengan pendekatan kuantitatif dan korelasional. Pengumpulan data dilaksanakan tanggal 9 September sampai dengan 15 Oktober 2014, terhadap 24 orang guru, sebagai subyek, yang berasal dari 5 (lima) desa di Kecamatan Tepus, Gunung Kidul. Populasi penelitian ini adalah seluruh guru-guru SD di Kecamatan Tepus Kabupaten Gunung Kidul yang telah bersertifikasi pendidik sampai dengan tahun 2012. Teknik pengambilan sampel penelitian yakni quota area random sampling. Jumlah keseluruhan sampel ditentukan $25 \%$ jumlah anggota populasi guru-guru SD di Kecamatan Tepus, Kabupaten Gunung Kidul (quota sampling). Masing-masing desa juga diambil $25 \%$ jumlah guru-guru SD di Kecamatan Tepus, Kabupaten Gunung Kidul.

Instrumen penelitian disusun peneliti berdasarkan aspek-aspek kompetensi pedagogik menurut Peraturan Pemerintah RI Nomor 74 Tahun 2008 tentang Guru. Pengumpulan data menggunakan metode observasi, dokumentasi, dan interview
Tabel 1. Kisi-kisi Instrumen Pengumpulan Data tentang Kompetensi Pedagogik Guru-Guru SD.

\begin{tabular}{|c|c|c|}
\hline Aspek & Butir & $\begin{array}{c}\text { Jumlah } \\
\text { Butir }\end{array}$ \\
\hline $\begin{array}{l}\text { Pemahaman wawasan atau landasan } \\
\text { kependidikan }\end{array}$ & $1,2,3,4$ & 4 butir \\
\hline Pemahaman terhadap peserta didik & $5,6,7,8$ & 4 butir \\
\hline $\begin{array}{l}\text { Penggunaan waktu dalam } \\
\text { pembelajaran }\end{array}$ & $9,10,11,12$ & 4 butir \\
\hline Penggunaan waktu dalam beristirahat & $13,14,15,16$ & 4 butir \\
\hline Pengembangan Kurikulum atau Silabus & $17,18,19,20$ & 4 butir \\
\hline Perancangan Pembelajaran & $21,22,23,24$ & 4 butir \\
\hline $\begin{array}{lll}\text { Pelaksanaan Pembelajaran yang } \\
\text { mendidik dan dialogis }\end{array}$ & $25,26,27,28$ & 4 butir \\
\hline Pemanfaatan Teknologi Pembelajaran & $29,30,31,32$ & 4 butir \\
\hline Evaluasi Hasil Belajar & $1,2,3,4$ & 4 butir \\
\hline $\begin{array}{l}\text { Pengembangan peserta didik untuk } \\
\text { mengaktualisasikan berbagai potensi } \\
\text { yang dimilikinya. }\end{array}$ & $5,6,7,8$ & 4 butir \\
\hline Jumlah & & 32 butir \\
\hline
\end{tabular}

Tabel 2. Kisi-kisi Instrumen Pengumpulan Data tentang Kedisiplinan Kerja Guru-Guru SD.

\begin{tabular}{llc}
\hline \multicolumn{1}{c}{ Aspek } & \multicolumn{1}{c}{ Butir } & $\begin{array}{c}\text { Jumlah } \\
\text { Butir }\end{array}$ \\
\hline Kedisiplinan waktu dalam mengajar & $1,2,3,4$ & 4 butir \\
Kehadiran dan kepulangan kerja & $5,6,7,8$ & 4 butir \\
Penggunaan waktu dalam & $9,10,11,12$ & 4 butir \\
pembelajaran & & \\
Penggunaan waktu dalam beristirahat & $13,14,15,16$ & 4 butir \\
\hline Jumlah & & \\
\hline
\end{tabular}

Kedua instrumen penelitian (kemampuan kompensasi pedagogik, dan kedisiplinan kerja), validitas instrumennya adalah validitas isi (content validity), sedangkan realibilitas instrumen menggunakan uji coba instrumen, yang hasilnya dianalisis menggunakan teknik analisis statistik Product Moment, dikoreksi 
menggunakan rumus Spearman Brown. Metode analisis data menggunakan teknik statistik deskriptif rerata, prosentase, dan tabulasi silang.

\section{HASIL PENELITIAN DAN PEMBAHASAN}

Hasil penelitian sebagai berikut pada tabel di bawah ini.

Tabel 3. Hasil Penelitian Kompetensi

Pedagogik Guru-guru SD yang

Bersertifikasi Pendidik di

Kecamatan Tepus, Gunung Kidul.

\begin{tabular}{|c|c|c|c|}
\hline No & Aspek & $\begin{array}{l}\text { Jumlah } \\
\text { Skor }\end{array}$ & $\begin{array}{c}\text { Prosentase } \\
(\%)\end{array}$ \\
\hline 1. & $\begin{array}{l}\text { Pemahaman wawasan atau } \\
\text { landasan kependidikan }\end{array}$ & 331 & 86 \\
\hline 2. & $\begin{array}{l}\text { Pemahaman terhadap peserta } \\
\text { didik }\end{array}$ & 335 & 87 \\
\hline 3. & $\begin{array}{l}\text { Pengembangan kurikulum } \\
\text { dan silabus }\end{array}$ & 316 & 82 \\
\hline 4. & Perancangan pembelajaran & 322 & 84 \\
\hline 5. & $\begin{array}{l}\text { Pelaksanaan pembelajaran } \\
\text { yang mendidik dan dialogis }\end{array}$ & 324 & 84 \\
\hline 6. & $\begin{array}{l}\text { Pemanfaatan teknologi } \\
\text { pembelajaran }\end{array}$ & 293 & 76 \\
\hline 7. & Evaluasi hasil belajar & 315 & 82 \\
\hline 8. & $\begin{array}{l}\text { Pengembangan peserta didik } \\
\text { untuk mengaktualisasikan } \\
\text { berbagai potensi yang } \\
\text { dimilikinya }\end{array}$ & 318 & 83 \\
\hline & Rata-rata & $\begin{array}{c}2.554: 8 \\
= \\
319\end{array}$ & 83 \\
\hline
\end{tabular}

Berdasarkan hasil penelitian dan analisis data tersebut di atas pada tabel, maka hasil penelitian tentang pemahaman wawasan atau landasan kependidikan sebesar $86 \%$, pemahaman terhadap peserta didik sebesar $87 \%$, pengembangan kurikulum dan silabus sebesar $82 \%$, perancangan pembelajaran sebesar $84 \%$, pelaksanaan pembelajaran yang mendidik dan dialogis sebesar $84 \%$, pemanfaatan teknologi pembelajaran sebesar $76 \%$, evaluasi hasil belajar sebesar $82 \%$, da pengembangan peserta didik untuk mengaktualisasikan berbagai potensi yang dimilikinya sebesar $83 \%$. Jadi rata-rata kemampuan atau kompetensi pedagogik guru-guru SD yang bersertifikasi pendidik di Kecamatan Tepus, Gunung Kidul sebesar $83 \%$, atau dalam kriteria bagus.

Jika dibuat tabulasi silang hasil penelitian tentang kompetensi pedagogik guru-guru SD yang bersertifikasi pendidik di Kecamatan Tepus, Gunung Kidul adalah

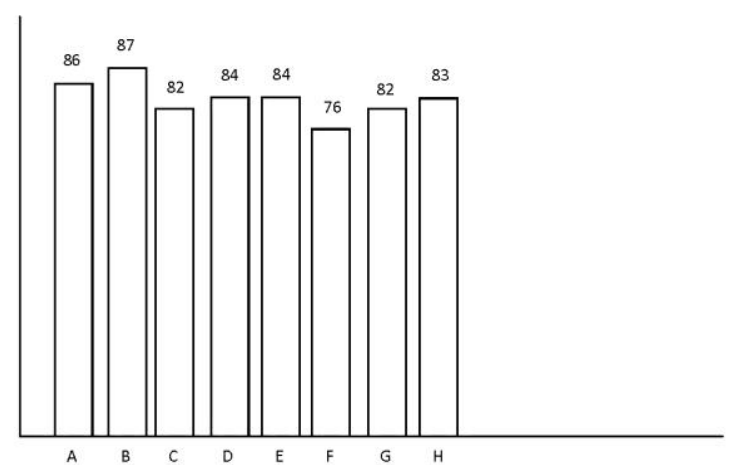

\footnotetext{
Keterangan :

$\mathrm{A}=$ Pemahaman wawasan atau landasan kependidikan

$\mathrm{B}=$ Pemahaman terhadap peserta didik

$\mathrm{C}=$ Pengembangan kurikulum dan silabus

$\mathrm{D}=$ Perancangan pembelajaran

$\mathrm{E}=$ Pelaksanaan pembelajaran yang mendidik dan dialogis

$\mathrm{F}=$ Pemanfaatan teknologi pembelajaran

$\mathrm{G}=$ Evaluasi hasil belajar

$\mathrm{H}=$ Pengembangan peserta didik untuk mengaktualisasikan berbagai potensi yang dimilikinya
}

Menilik tabulasi silang tersebut maka aspek kompetensi pedagogik yang paling tinggi adalah pemahaman terhadap peserta 
didik, yakni $87 \%$, sedangkan yang terendah adalah aspek pemanfaatan teknologi pembelajaran, yakni 76\%. Namun secara rata-rata masih dalam kriteria bagus yakni $83 \%$.

Hasil penelitian tentang kedisiplinan kerja guru-guru SD yang bersertifikasi pendidik di Kecamatan Tepus, Gunung Kidul adalah sebagai berikut pada tabel di bawah ini.

Tabel 4. Hasil Penelitian Kedisiplinan Kerja Guru-guru SD yang Bersertifikasi Pendidik di Kecamatan Tepus, Gunung Kidul

\begin{tabular}{llcc}
\hline No & \multicolumn{1}{c}{ Aspek } & $\begin{array}{c}\text { Jumlah } \\
\text { Skor }\end{array}$ & $\begin{array}{c}\text { Prosentase } \\
(\mathbf{\%})\end{array}$ \\
\hline 1. & $\begin{array}{l}\text { Kedisiplinan waktu } \\
\text { dalam mengajar }\end{array}$ & 322 & 84 \\
2. & $\begin{array}{l}\text { Kehadiran dan } \\
\text { kepulangan kerja }\end{array}$ & 290 & 75,5 \\
3. & $\begin{array}{l}\text { Penggunaan waktu } \\
\text { dalam pembelajaran }\end{array}$ & 269 & 70 \\
4. & $\begin{array}{l}\text { Penggunaan waktu } \\
\text { dalam beristirahat }\end{array}$ & 268 & 70 \\
\hline & Rata-rata & $\begin{array}{c}\mathbf{1 . 1 4 9 : 4} \\
\mathbf{2}\end{array}$ & $\mathbf{7 5}$ \\
\hline
\end{tabular}

Berdasarkan hasil penelitian yang tertera pada tabel tersebut di atas menunjukkan bahwa kedisiplinan waktu dalam mengajar adalah $84 \%$, kehadiran dan kepulangan kerja adalah $75,5 \%$, penggunaan waktu dalam pembelajaran adalah $70 \%$, Penggunaan waktu dalam beristirahat adalah $70 \%$. Jadi rata-rata kedisiplinan kerja guru-guru SD yang bersertifikasi pendidik di Kecamatan Tepus, Gunung Kidul adalah $75 \%$ atau dalam kriteria bagus.

Jika dibuat tabulasi silang hasil penelitian tentang kedisiplinan kerja guruguru SD yang bersertifikasi pendidik di Kecamatan Tepus, Gunung Kidul adalah sebagai berikut :

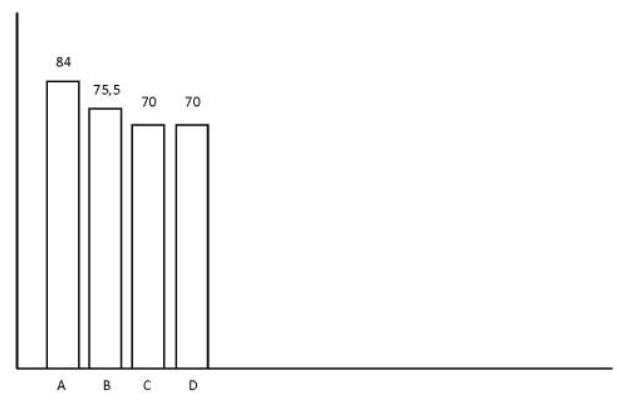

Keterangan :

$\mathrm{A}=$ Kedisiplinan waktu dalam mengajar

$\mathrm{B}=$ Kehadiran dan kepulangan kerja

$\mathrm{C}=$ Penggunaan waktu dalam pembelajaran

$\mathrm{D}=$ Penggunaan waktu dalam beristirahat

Berdasarkan hasil penelitian yang tertera pada tabulasi silang tersebut di atas menunjukkan bahwa aspek kedisiplinan kerja yang tertinggi adalah kedisiplinan waktu dalam mengajar yakni $84 \%$, sedangkan yang terendah adalah aspek penggunaan waktu dalam pembelajaran dan penggunaan waktu dalam beristirahat, yakni 70\%. Secara keseluruhan, rata-rata kedisiplinan kerja guru-guru SD yang bersertifikat pendidik di Kecamatan Tepus, Gunung Kidul adalah 75\%, yakni dalam kriteria bagus. 
Kemampuan atau kompetensi pedagogik guru-guru SD yang bersertifikasi pendidik di Kecamatan Tepus, Gunung Kidul.

Hasil penelitian dan analisis data tentang kompetensi pedagogik guru-guru SD yang bersertifikasi pendidik di Kecamatan Tepus, Gunung Kidul adalah $83 \%$ atau berkriteria bagus. Para guru SD yang sudah bersertifikasi pendidik terbukti melaksanakan tugas secara bagus. Hal ini disebabkan makin meningkatnya kemampuan melaksanakan pembelajaran, yang telah dipersiapkan sejak akan mengikuti pendidikan dan latihan profesi guru (PLPG) dan juga dalam pelaksanaan PLPG.

Dalam pelaksanaan PLPG, para guru dibina dan dibimbing dalam pendalaman materi pembelajaran, metode atau modelmodel pembelajaran, penelitian tindakan kelas, dan praktek pembelajaran. Hal ini akan menambah wawasan dan kemampuan para guru, khususnya dalam bidang kompetensi pedagogik, di samping kompetensi sosial, kompetensi kepribadian, dan kompetensi profesional. Kemampuan para guru SD ini tetap diimplementasikan dalam melaksanakan tugas sehari-hari dalam pembelajaran.
Para guru SD juga makin meningkat kesadarannya dalam melaksanakan tugas mulia, yakni mengutamakan pendewasaan peserta didik dalam proses pembelajaran khususnya, proses pendidikan pada umumnya. Guru-guru selalu meningkatkan kemampuan atau kompetensinya, baik secara individu, maupun secara kelompok, yakni dalam KKG (Kelompok Kerja Guru) setiap satu minggu sekali.

Kontinuitas pembelajaran yang terusmenerus ditempuh oleh guru, mengakibatkan kemampuan dan kompetensi pedagogiknya selalu sesuai perkembangan waktu dan tempat berdasarkan kondisi peserta didik dan lingkungan sekitar. Guru selalu meningkatkan pengetahuan, ilmu, dan ketrampilannya melalui membaca buku, media cetak, dan mengikuti perkembangan ilmu pengetahuan melalui teknologi dan komunikasi.

Kedisiplinan kerja guru-guru SD yang bersertifikasi pendidik di Kecamatan Tepus, Gunung Kidul.

Hasil penelitian dan analisis data tentang kedisiplinan kerja guru-guru SD yang bersertifikasi pendidik di Kecamatan Tepus, Gunung Kidul adalah $75 \%$ atau berkriteria bagus. Para guru SD yang bersertifikasi pendidik makin meningkat 
kesadaran kedisiplinan kerjanya, sebab sejak mempersiapkan diri akan mengikuti PLPG (Pendidikan dan Latihan Profesi Guru), pembagian waktu sangat berperan sekali termasuk saat mengikuti PLPG, maka kedisiplinan waktu sangat penting dalam pelaksanaannya, demi suksesnya mencapai kelulusan PLPG.

Juga pada saat sesudah bersertifikasi pendidik, para guru SD makin sadar dan makin meningkat penampilan dan unjuk kerjanya demi kesuksesan pembelajaran peserta didiknya. Peningkatan kedisiplinan kerja, terdorong juga oleh peningkatan perhatian pemerintah dalam hal kesejahteraan kehidupan guru, khususnya guru SD. Kesejahteraan yang dirasa besar guru berakibat makin tingginya rasa kesadaran dalam penggunaan waktu pada saat bekerja sebagai guru.

Jadi peningkatan kesejahteraan, peningkatan kesadaran, akan perlunya disiplin waktu, berperan terhadap peningkatan unjuk kerja, dan terutama peningkatan kualitas belajar para peserta didik.

\section{KESIMPULAN DAN SARAN} Kesimpulan
Berdasarkan analisis data tersebut di muka, maka dapat disimpulkan hasil penelitian ini sebagai berikut :

1. Kompetensi pedagogik guru-guru SD yang bersertifikasi pendidik di Kecamatan Tepus, Gunung Kidul dalam kondisi bagus (83\%).

2. Kedisiplinan kerja guru-guru SD yang bersertifikasi pendidik di Kecamatan Tepus, Gunung Kidul, dalam kondisi bagus $(75 \%)$.

\section{Saran}

Berdasarkan kesimpulan penelitian di atas, ada beberapa saran yang dapat disampaikan yaitu:

1. Perlu selalu diadakan monitoring dan pembinaan terhadap guru-guru yang bersertifikasi pendidik, supaya tetap selalu menampilkan kompetensi pedagogik yang semakin bagus.

2. Perlu kesadaran kedisiplinan kerja guru-guru SD yang bersertifikasi pendidik, sehingga betul-betul meningkatkan unjuk kerjanya, demi peningkatan kualitas pembelajaran, hasil belajar, dan pendidikan pada umumnya. 


\section{DAFTAR PUSTAKA}

Eny Susilowati. 2009. Tiga Tipe Guru. Harian Kedaulatan Rakyat, Selasa 3 Februari 2009.

Giyono, Wisnu. 2010. Kemampuan Menggunakan Media Pembelajaran Guru-Guru SD di Kecamatan Kretek, Bantul. Laporan Penelitian. Yogyakarta UST.

Giyono, Wisnu. 2006. Kemampuan Mengajar Guru-Guru SD di Kecamatan Kretek, Bantul. Laporan Penelitian Yogyakarta. Akpar Buana Wisata.

Palupi Panca Astuti. 2006. Peran Guru dalam Meningkatkan Mutu Pendidikan. Harian Kompas, Kamis 2 Maret 2006.

Peraturan Menteri Pendidikan Nasional Republik Indonesia No. 18 tahun 2007 tentang sertifikasi bagi Guru dalam jabatan. http://sertifikasiguru.or/index.php.pa ge:permen 1097 .

Sugiman dan Giyana. 2001. Upaya Peningkatan Belajar Matematika Melalui Pembinaan Teknologi Pembelajaran di Sekolah Dasar di Kabupaten Kulon Progo, Yogyakarta. Laporan Penelitian UNY. Tidak diterbitkan.

Sumardi. 2009. Guru Pandang Sertifikasi hanya untuk Gaji. Harian Kedaulatan Rakyat. Selasa 3 Februari 2009.

Warniasih, Kristina. 2011. Kemempuan Menggunakan Alat Peraga Pada mata Pelajaran Matematika GuruGuru SD di Kecamatan Pajangan Bantul. Laporan Penelitian. Yogyakarta. UPY.
Wahyumiami, Nur dkk.2003. Hubungan Kepemimpinan Kepala Sekolah dan Kedisiplinan Kerja dengan Kemampuan Mengajar Guru-Guru SD di Kecamatan Pajangan Bantul. Laporan Penelitian. Yogyakarta: IKIP PGRI Yogyakarta.

Wilardjo. L. 2014. Guru. Harian Kompas 2 Februari 2014. 